\title{
Metabolic risk factors of coronary heart disease in relation to anthropometric measures in nonalcoholic fatty liver disease patients following dietary intervention
}

\author{
Metaboliczne czynniki ryzyka choroby niedokrwiennej serca a pomiary antropometryczne \\ u pacjentów z niealkoholową stłuszczeniową chorobą wątroby stosujących \\ indywidualny plan żywieniowy
}

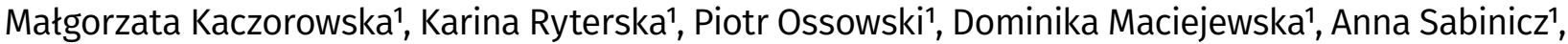 \\ Dominika Jamioł-Milcㄱ, Joanna Raszeja-Wyszomirska², Ewa Stachowska1 ${ }^{\circledR}$
}

1 Pomorski Uniwersytet Medyczny w Szczecinie, Zakład Biochemii i Żywienia Człowieka, ul. Broniewskiego 24, 71-460 Szczecin ${ }^{2}$ Warszawski Uniwersytet Medyczny, Klinika Chirurgii Ogólnej, Transplantacyjnej i Wątroby, ul. Banacha 1A, 02-097 Warszawa $\triangle$ ewa.stachowska@pum.edu.pl

\begin{abstract}
Introduction: Nonalcoholic fatty liver disease (NAFLD) is connected with high risk of metabolic disorders, such as: metabolic syndrome, type 2 diabetes, dyslipidemia and independently, coronary heart disease (CHD).

Materials and methods: A group of 108 Caucasian individuals (39 women and 69 men) aged 20-77 years with NAFLD were prospectively enrolled in the study. The diagnosis of NAFLD was confirmed during the first appointment using ultrasonography. The liver serum tests such as alanine aminotransferase and aspartate aminotransferase levels were taken into account, as well. All of the tests and measurements were taken at the begining and after 6 month of dieting. Anthropometric tools (body mass index - BMI, waist circumference - WC, waist to hip ratio - WHR waist to height ratio - WHtR, coinicity index - C-Index) were examined in relation to metabolic risk factors of CHD (increased:
\end{abstract}

triacylglycerols, low density lipoprotein, total cholesterol, glycemia and low high density lipoprotein).

Results: Statistical significant reduction of body weight, BMI, WC, WHR, WHtR and C-Index $(\mathrm{p}<0.05)$ contributed to the improvement of serum triacylglycerols in both sexes $(p<0.05)$. Indicators of abdominal obesity (WC, WHR, WHtR, C-Index) correlated significantly with serum glucose $(p<0.05)$ both before and after the diet and with serum lipids, either before or after the diet $(\mathrm{p}<0.05)$, in both sexes.

Conclusions: It seems beneficial to spread the use of anthropometric tools, especially C-Index and WHtR, in primary health care practice for either early prevention or prediction of metabolic CHD risk occurrence, and its potential fatal consequences among patients with NAFLD or with other metabolic disorders. Keywords: fatty liver disease; cardiovascular disease; risk factors; anthropometry; nutrition; metabolic syndrome.

\begin{abstract}
ABSTRAKT
Wstęp: Niealkoholowa stłuszczeniowa choroba wątroby (NAFLD) jest związana z wysokim ryzykiem zaburzeń metabolicznych (zespół metaboliczny, cukrzyca typu 2) oraz choroby wieńcowej. Materiały i metody: Grupę badaną stanowiło 108 osób dorosłych rasy kaukaskiej (39 kobiet i 69 mężczyzn) w wieku 20-77 lat z rozpoznaną NAFLD. Podstawą diagnozy było dokładne badanie USG wątroby oraz analiza parametrów wątrobowych: aminotransferazy alaninowej i aminotransferazy asparaginianowej w surowicy. Wszystkie badania przeprowadzono podczas pierwszej i ostatniej wizyty pacjentów w placówce badawczej (po 6 miesiącach od interwencji dietetycznej). Dokonywano także pomiarów antropometrycznych (wskaźnik masy ciałaBMI, obwód pasa - WC, wskaźnik talia-biodra - WHR, wskaźnik talia-wzrost - WHtR, wskaźnik stożkowatości - C-Index) w odniesieniu do metabolicznych czynników ryzyka choroby niedokrwiennej serca (podwyższone stężenie w surowicy:
\end{abstract}

triacylogliceroli, cholesterolu lipoprotein niskiej gęstości, cholesterolu całkowitego, glukozy oraz obniżone stężenie cholesterolu lipoprotein wysokiej gęstości).

Wyniki: Zarówno w grupie kobiet, jak i mężczyzn wykazano istotną statystycznie redukcję wartości parametrów takich jak: masa ciała, BMI, WC, WHR, WHtR i C-Index $(\mathrm{p}<0,05)$, co miało wpływ na poprawę stężenia triacylogliceroli w surowicy u obu płci $(\mathrm{p}<0,05)$. Wskaźniki identyfikujące otyłość brzuszną (WC, WHR, WHtR, C-Index) korelowały istotnie z wartością glikemii $(\mathrm{p}<0,05)$ zarówno przed interwencją dietetyczną, jak i po niej oraz ze stężeniem lipidów w surowicy przed interwencją lub po $(\mathrm{p}<0,05)$ u obu płci.

Wnioski: Rozpowszechnienie użycia prostych narzędzi antropometrycznych (przede wszystkim C-Index i WHtR) wydaje się być korzystne, zwłaszcza na szczeblu podstawowej opieki zdrowotnej. Narzędzia te mogą służyć zarówno do prewencji, jak i wczesnego wykrywania metabolicznych czynników ryzyka 
choroby niedokrwiennej serca, a co za tym idzie potencjalnie śmiertelnych konsekwencji incydentów wieńcowych u pacjentów z NAFLD lub z innymi zaburzeniami metabolizmu.
Słowa kluczowe: stłuszczeniowa choroba wątroby; choroby sercowo-naczyniowe; czynniki ryzyka; antropometria; żywienie; zespół metaboliczny.

\section{INTRODUCTION}

Nonalcoholic fatty liver disease (NAFLD) is one of the most recognized chronic diseases of the liver, and is diagnosed even at an early age [1]. In the latest reports, researchers classify NAFLD as one of the components of the metabolic syndrome [2]. Nonalcoholic fatty liver disease is a health problem affecting an increasing number of populations in developed countries. It is estimated to occur in $20-44 \%$ of Europeans [3] and in at least $30 \%$ of the citizens in the USA $[1,4]$. Moreover, NAFLD is particularly prevalent in type 2 diabetic patients (42.6-69.5\%) [5] and among obese and morbidly obese individuals (about 80\%) [6]. The basic concept to explain the primary hepatic steatosis mechanism in the development of nonalcoholic steatohepatitis is based on the 'two-hit' theory [7]. In 2013, a new mechanism for the development of NAFLD was proposed, which involved oxidized low density lipoprotein in NAFLD pathogenesis [8]. The efficacy and safety profile of pharmacotherapy in the treatment of NAFLD are questionable [7]. According to the results of epidemiologic studies, saturated fat, trans-fatty acid, and carbohydrate (simple sugar) correlate strongly with intrahepatic fat accumulation [9]. Thus, lifestyle modification including changes in dietary pattern as well as increasing physical activity level are considered first-line therapy for NAFLD, due to the fact that obesity is strongly related to hepatic steatosis [6]. However, rapid reduction of body mass can lead to increased inflammation in the liver and exacerbate steatosis [10]. Preventive programs concerning dietary and lifestyle recommendations from early childhood should be followed [7,11], aiming to reduce the risk of obesity at an early age [12]. Cardiovascular disease (CVD) became the dominant health problem in the late XIX and early XX century [13], and remains the leading cause of death in developed countries [14]. Fundamental cohort studies with an invaluable impact on the current knowledge of CVD $[15,16,17]$ have confirmed the importance of underlying risk factors such as diabetes, hypertension, dyslipidemia, and smoking in the development of coronary heart disease (CHD) [18]. It is estimated that in the European population, CVD causes 4.3 million deaths per year, of which nearly $45 \%$ is due to CHD [19]. In the European population, CHD remains the leading single cause of death in both sexes [20]. Obesity, especially visceral, predisposes individuals to multiple coexisting risk factors for CVD. It is very often associated with metabolic abnormalities (dyslipidemia, hypertension, insulin resistance, hyperinsulinemia, diabetes) [21], which increase the likelihood of cardiovascular events, including coronary events [22, 23].

Imaging methods allow very precise evaluation of fat accumulation in the body. Nevertheless, the high costs and complexity of these techniques limit their use in epidemiological studies and clinical diagnosis. Therefore, anthropometric methods, which are simple to use, easy to interpret, non-invasive and inexpensive, have become popular for the assessment of body fat [24]. Body mass index (BMI) is the most common indicator used to assess body fat [25]. Waist circumference (WC) and waist to hip ratio (WHR) are the most popular indices used in the assessment of abdominal adipose tissue distribution in individual patients and in cohort studies $[21,26]$. Other indicators which have been demonstrated to correlate with CVD risk are the conicity index (C-Index) and waist to height ratio (WHtR). For WHtR, the border value of 0.5 has been established as universal for both sexes, all ages and races [25]. Below a particular cut-off point it is possible to exclude the risk of CVD [27, 28].

The rapid, inexpensive and accurate diagnosis of possible risk factors for cardiovascular events, as well as NAFLD, using simple anthropometric measurements as screening tools in early diagnosis, seems to be a practical application of these tools in primary healthcare facilities. Therefore we aim to analyze the correlation between basic anthropometric tools and certain CHD risk factors in NAFLD patients following individual nutrition plan.

\section{MATERIALS AND METHODS}

\section{Patients}

A 6-month study was conducted in the Department of Biochemistry and Human Nutrition in the Pomeranian Medical University in Szczecin (Poland). A group of 108 Caucasian individuals (39 women and 69 men) aged 20-77 years and diagnosed with NAFLD were prospectively enrolled in the study. The diagnosis of NAFLD was confirmed during the first appointment using ultrasonography. The liver serum tests such as alanine aminotransferase and aspartate aminotransferase levels were taken into account, as well. Written informed consent was obtained from each study participant. All subjects included in the study were negative for both hepatitis B virus and HCV hepatitis $C$ virus, excessive consumption of alcohol ( $\geq 20 \mathrm{~g}$ in women and $\geq 30$ g in men, per day), mortal obesity (BMI $>40 \mathrm{~kg} / \mathrm{m}^{2}$ ) and high levels of physical activity $(>3000 \mathrm{kcal} /$ week in leisure-time) were excluded. The reception of medication and the presence of previous diagnosed other chronic diseases (apart from already diagnosed NAFLD) were excluded. Blood collection and all anthropometric measurements were undertaken at baseline and after 6-month dietary intervention.

\section{Standard blood biochemical analyses}

After an overnight fast, venous blood was collected and placed in tubes with anticoagulant for lipid analyses. Whole blood was collected and placed in ethylenediaminetetraacetic acid tubes. Blood was immediately placed on ice or in a refrigerator, 
and the samples were centrifuged at $3500 \mathrm{rpm}$ for $10 \mathrm{~min}$ at $4^{\circ} \mathrm{C}$ within 2 hours of collection. Plasma was then immediately stored under conditions to minimize artificial oxidation (i.e., with an antioxidant cocktail in an inert atmosphere). Standard blood biochemical analyses were carried out at the University Hospital Laboratory.

\section{Anthropometric measurements}

Waist to hip ratio was calculated by dividing WC (cm) by hip circumference $(\mathrm{cm})$. Waist to height ratio was determined by dividing WC $(\mathrm{cm})$ by height $(\mathrm{cm})$. The $\mathrm{C}$-Index calculation is based on weight, height and WC measurements [28]. The correct values of C-Index are below 1.18 and 1.25 for women and men, respectively. The C-Index allows a comparison of 2 individuals with different weight and height. Nevertheless, there is still little scientific information available regarding this tool. Therefore, its application in research and in cohort studies throughout the world is limited [25].

The C-Index was calculated using the following mathematical equation [24]:

$$
\text { C-Index }=\frac{\text { waist circumference }(\mathrm{m})}{0,109 \times \sqrt{\frac{\text { bodyweight }(\mathrm{kg})}{\text { height }(\mathrm{m})}}}
$$

Body mass index is the most common indicator used to assess body fat. Appropriate BMI values and deviations from the norm are known by both professionals and individuals not associated with healthcare. Although BMI is a good indicator in the assessment of nutritional status, it has limitations in assessing the distribution of body fat [25]. Body mass index was calculated by dividing body weight $(\mathrm{kg})$ by height squared $\left(\mathrm{m}^{2}\right)$

The cut-off points for WC in relation to disease risk are as follows: for women and men, respectively:

$-\leq 79.9$ and $\leq 93.9$ - low risk,

- 80.0-87.9 and 94.0-101.9 - increased risk,

$-\geq 88.0$ and $\geq 102$ - high risk of comorbidities [21, 26].

The cut-off points for WHR in relation to disease risk are as follows: for women and men, respectively:

$-<0.85$ and $<0.9$ - low risk,

-0.85 and 0.9 - increased risk,

$->0.85$ and $>0.9-$ high risk of comorbidities $[21,26]$.

\section{Diet intervention and control}

Total energy intake was calculated for each patient individually, taking into account age, sex and level of physical activity. Each patient received the diet adjusted to individual nutritional status. For overweight or obese subjects energy intake was reduced by $500 \mathrm{kcal} /$ day.

The content of essential nutrients in the diet (per day) was estimated as follows [7]: proteins $-1 \mathrm{~g} / \mathrm{kg}$ body weight; fats $25-30 \%$ of energy requirement; carbohydrates $-50-60 \%$ of energy requirement; fiber - minimum of $30 \mathrm{~g}$; vitamins and minerals - according to Recommended Dietary Allowance.

Patients were asked to complete the 72-hour food diary at home each day before the control appointment. The diet diary booklet contained menus, pages to record foods, and photographs of food that depicted portion choices for a common food item. The dietitian indicated that the patient should record the food brand and portion size. The amounts consumed were recorded in household units, by volume or by measuring with a ruler. Each subject was interviewed about their dietary pattern in the previous month. Nutrient analyses were carried out using the corresponding Polish food table [29] and the nutrient database developed in Poland (Dietetyk, Jumar, Poland).

\section{Statistic}

The collected data, obtained anthropometric measurements as well as input and output values of blood parameters were subjected to statistical analysis. All analyses were performed using the statistical package R (version 3.0.1 dated 16 May 2013). The Anderson-Darling test was used to examine distribution normality, and the Grubsson test was used to remove outliers. Data on non-parametric distributions were normalized. Regression analysis based on the Pearson correlation was used. The results were next subjected to the Wilcoxon matched-pairs test. Probability values below 0.05 were considered statistically significant $(\mathrm{p}<0.05)$.

\section{RESULTS}

Following 6 months of dietary intervention, numerous differences in the investigated variables were observed in the patients enrolled in this study $(n=108)$. Anthropometric parameters shifted significantly toward lower values compared to the data collected before dietary intervention (Table 1).

Similar to the results for the entire group of participants, for women $(n=39)$ and men $(n=69)$ the analysis demonstrated statistically significant differences between the mean values of anthropometric variables, such as weight, WC, BMI, WHR, WHtR and C-Index recorded before and after the diet intervention (Table 2).

In the entire group of patients, a number of statistically significant correlations between anthropometric indices and biochemical parameters after the dietary intervention were observed (Table 3).

The analysis of measurements in the entire group of women and men after the dietary intervention showed numerous statistically significant correlations, undetected before the diet (Table 4).

\section{DISCUSSION}

Incorrect body weight and excessive visceral adipose tissue accumulation contribute to the progression of fat accumulation in the liver. Increased visceral fat synthesis results in impaired systemic metabolism of carbohydrates and lipids, which is linked with the intensification of atherosclerosis [1]. Therefore, NAFLD patients may be at risk of CVD. 
TABLE 1. Characteristics of the study participants before and after dietary intervention

\begin{tabular}{|c|c|c|c|c|c|c|c|c|c|}
\hline \multirow{2}{*}{ Characteristic } & \multicolumn{4}{|c|}{ Before } & \multicolumn{4}{|c|}{ After } & \multirow{2}{*}{$p$} \\
\hline & mean $( \pm S D)$ & median & $\min$. & max. & mean $( \pm S D)$ & median & $\min$. & max. & \\
\hline Age (years) & $49.59( \pm 12.47)$ & 50.61 & 19.53 & 76.53 & $50.09( \pm 12.47)$ & 51.11 & 20.03 & 77.03 & - \\
\hline Weight (kg) & $92.25( \pm 16.73)$ & 90.40 & 55.00 & 146.00 & $86.75( \pm 15.32)$ & 86.48 & 53.26 & 127.60 & $<0.001$ \\
\hline WC (cm) & $103.67( \pm 11.87)$ & 103.00 & 78.00 & 146.00 & $97.89( \pm 12.10)$ & 98.00 & 72.00 & 136.00 & $<0.001$ \\
\hline BMI $\left(\mathrm{kg} / \mathrm{m}^{2}\right)$ & $31.78( \pm 4.95)$ & 31.47 & 22.60 & 48.12 & $29.92( \pm 4.79)$ & 29.75 & 21.47 & 48.03 & $<0.001$ \\
\hline WHR & $0.96( \pm 0.07)$ & 0.95 & 0.80 & 1.14 & $0.93( \pm 0.07)$ & 0.93 & 0.76 & 1.12 & $<0.001$ \\
\hline WHtR & $0.61( \pm 0.07)$ & 0.60 & 0.48 & 0.90 & $0.58( \pm 0.08)$ & 0.57 & 0.43 & 0.83 & $<0.001$ \\
\hline C-Index & $1.30( \pm 0.07)$ & 1.28 & 1.15 & 1.51 & $1.26( \pm 0.08)$ & 1.26 & 1.08 & 1.42 & $<0.001$ \\
\hline $\mathrm{TG}(\mathrm{mg} / \mathrm{dL})$ & $144.62( \pm 179.69)$ & 118.00 & 27.00 & 1908.00 & $140.43( \pm 139.25)$ & 106.50 & 29.00 & 1306.00 & 0.0017 \\
\hline $\begin{array}{l}\text { Total cholesterol } \\
\text { (mg/dL) }\end{array}$ & $202.69( \pm 46.84)$ & 196.00 & 100.00 & 420.00 & $199.76( \pm 49.42)$ & 197.50 & 52.00 & 340.00 & 0.5555 \\
\hline LDL (mg/dL) & $123.13( \pm 38.09)$ & 121.50 & 41.00 & 235.00 & $126.41( \pm 58.23)$ & 113.50 & 30.00 & 464.00 & 0.2631 \\
\hline Glucose (mg/dL) & $108.27( \pm 29.73)$ & 102.00 & 48.00 & 282.00 & $109.77( \pm 32.83)$ & 102.00 & 71.00 & 337.00 & 0.9703 \\
\hline $\mathrm{HDL}(\mathrm{mg} / \mathrm{dL})$ & $50.99( \pm 15.82)$ & 48.00 & 21.00 & 131.00 & $53.20( \pm 16.38)$ & 50.50 & 26.00 & 111.00 & 0.2611 \\
\hline
\end{tabular}

WC - waist circumference; BMI - body mass index; WHR - waist to hip ratio; WHtR - waist to height ratio; C-Index - coinicity index; TG - triacylglycerols; LDL - low density lipoprotein; HDL - high density lipoprotein

TABLE 2. Characteristics of the enrolled women and men before and after dietary intervention

\begin{tabular}{|c|c|c|c|c|c|c|c|c|c|}
\hline \multirow{2}{*}{ Characteristic } & \multicolumn{4}{|c|}{ Before } & \multicolumn{4}{|c|}{ After } & \multirow{2}{*}{$p$} \\
\hline & mean $( \pm S D)$ & median & $\min$. & max. & mean $( \pm S D)$ & median & $\min$. & max. & \\
\hline \multicolumn{10}{|c|}{ Group of women } \\
\hline Age (years) & $55.37( \pm 11.27)$ & 56.20 & 19.53 & 74.93 & $55.87( \pm 11.27)$ & 56.70 & 20.03 & 75.43 & - \\
\hline Weight (kg) & $84.15( \pm 15.56)$ & 81.20 & 55.00 & 127.85 & $79.55( \pm 15.53)$ & 77.80 & 53.26 & 127.60 & $<0.001$ \\
\hline WC (cm) & $101.96( \pm 12.65)$ & 102.00 & 78.00 & 146.00 & $95.78( \pm 13.18)$ & 98.00 & 72.00 & 136.00 & $<0.001$ \\
\hline BMI $\left(\mathrm{kg} / \mathrm{m}^{2}\right)$ & $33.14( \pm 5.37)$ & 32.28 & 22.60 & 48.12 & $31.31( \pm 5.37)$ & 30.86 & 21.47 & 48.03 & $<0.001$ \\
\hline WHR & $0.93( \pm 0.06)$ & 0.92 & 0.80 & 1.04 & $0.90( \pm 0.07)$ & 0.90 & 0.76 & 1.09 & 0.0244 \\
\hline WHtR & $0.64( \pm 0.08)$ & 0.65 & 0.50 & 0.90 & $0.60( \pm 0.08)$ & 0.59 & 0.46 & 0.83 & $<0.001$ \\
\hline C-Index & $1.29( \pm 0.08)$ & 1.30 & 1.15 & 1.51 & $1.25( \pm 0.09)$ & 1.24 & 1.08 & 1.41 & 0.0013 \\
\hline TG (mg/dL) & $179.41( \pm 287.23)$ & 125.00 & 27.00 & 1908.00 & $166.44( \pm 198.35)$ & 115.00 & 29.00 & 1306.00 & 0.0367 \\
\hline $\begin{array}{l}\text { Total cholesterol } \\
\text { (mg/dL) }\end{array}$ & $214.00( \pm 52.49)$ & 204.00 & 116.00 & 420.00 & $212.85( \pm 49.82)$ & 203.00 & 81.00 & 340.00 & 0.8561 \\
\hline LDL (mg/dL) & $125.41( \pm 39.83)$ & 122.00 & 47.00 & 235.00 & $124.51( \pm 37.87)$ & 123.00 & 35.00 & 233.00 & 0.8221 \\
\hline Glucose (mg/dL) & $117.72( \pm 40.82)$ & 104.00 & 85.00 & 282.00 & $119.28( \pm 46.52)$ & 105.00 & 83.00 & 337.00 & 0.3296 \\
\hline $\mathrm{HDL}$ (mg/dL) & $53.77( \pm 17.76)$ & 50.00 & 29.00 & 131.00 & $55.87( \pm 17.29)$ & 54.00 & 30.00 & 111.00 & 0.4607 \\
\hline \multicolumn{10}{|c|}{ Group of men } \\
\hline Age (years) & $46.32( \pm 11.98)$ & 45.12 & 27.47 & 76.53 & $46.82( \pm 11.98)$ & 45.62 & 27.97 & 77.03 & - \\
\hline Weight (kg) & $96.83( \pm 15.70)$ & 93.80 & 69.10 & 146.00 & $90.83( \pm 13.71)$ & 89.00 & 66.70 & 122.30 & $<0.001$ \\
\hline WC (cm) & $104.64( \pm 11.38)$ & 103.50 & 88.00 & 136.00 & $99.08( \pm 11.37)$ & 98.50 & 81.00 & 129.00 & $<0.001$ \\
\hline BMI $\left(\mathrm{kg} / \mathrm{m}^{2}\right)$ & $31.02( \pm 4.55)$ & 30.10 & 23.02 & 44.08 & $29.13( \pm 4.28)$ & 28.51 & 21.53 & 39.90 & $<0.001$ \\
\hline WHR & $0.97( \pm 0.06)$ & 0.97 & 0.86 & 1.14 & $0.95( \pm 0.06)$ & 0.95 & 0.79 & 1.12 & $<0.001$ \\
\hline WHtR & $0.59( \pm 0.07)$ & 0.59 & 0.48 & 0.76 & $0.56( \pm 0.07)$ & 0.55 & 0.43 & 0.74 & $<0.001$ \\
\hline C-Index & $1.30( \pm 0.07)$ & 1.28 & 1.15 & 1.46 & $1.27( \pm 0.07)$ & 1.27 & 1.12 & 1.42 & $<0.001$ \\
\hline TG (mg/dL) & $124.96( \pm 60.13)$ & 109.00 & 45.00 & 373.00 & $125.72( \pm 88.99)$ & 101.00 & 32.00 & 426.00 & 0.0195 \\
\hline $\begin{array}{l}\text { Total cholesterol } \\
(\mathrm{mg} / \mathrm{dL})\end{array}$ & $196.30( \pm 42.41)$ & 189.00 & 100.00 & 302.00 & $192.36( \pm 47.98)$ & 193.00 & 52.00 & 319.00 & 0.6163 \\
\hline LDL (mg/dL) & $121.84( \pm 37.31)$ & 120.00 & 41.00 & 208.00 & $127.48( \pm 67.32)$ & 111.00 & 30.00 & 464.00 & 0.2412 \\
\hline Glucose (mg/dL) & $102.93( \pm 19.48)$ & 100.00 & 48.00 & 201.00 & $104.39( \pm 20.13)$ & 102.00 & 71.00 & 230.00 & 0.4546 \\
\hline $\mathrm{HDL}(\mathrm{mg} / \mathrm{dL})$ & $49.42( \pm 14.50)$ & 47.00 & 21.00 & 107.00 & $51.70( \pm 15.77)$ & 47.00 & 26.00 & 107.00 & 0.4595 \\
\hline
\end{tabular}

WC - waist circumference; BMI - body mass index; WHR - waist to hip ratio; WHtR - waist to height ratio; C-Index - coinicity index; TG - triacylglycerols; LDL - low density lipoprotein; HDL - high density lipoprotein 
TABLE 3. Correlations in the entire group of participants before and after dietary intervention

\begin{tabular}{|c|c|c|c|c|c|}
\hline \multirow[b]{2}{*}{ Correlations } & \multicolumn{2}{|c|}{ Before } & \multirow[b]{2}{*}{ Correlations } & \multicolumn{2}{|c|}{ After } \\
\hline & $\mathrm{p}$ & $\begin{array}{c}\text { correlation } \\
\text { estimates value }\end{array}$ & & p & $\begin{array}{c}\text { correlation } \\
\text { estimates value }\end{array}$ \\
\hline BMI-TG & $>0.05$ & - & BMI-TG & 0.0140 & 0.24 \\
\hline BMI-Glucose & $>0.05$ & - & BMI-Glucose & 0.0023 & 0.29 \\
\hline WHR-Glucose & 0.0047 & 0.27 & WHR-Glucose & 0.0117 & 0.24 \\
\hline WHR-HDL & 0.0134 & -0.24 & WHR-HDL & 0.0406 & -0.20 \\
\hline WHtR-TG & 0.0362 & 0.20 & WHtR-TG & 0.0058 & 0.26 \\
\hline WHtR-Glucose & 0.0002 & 0.35 & WHtR-Glucose & 0.0001 & 0.38 \\
\hline WC-Glucose & 0.0320 & 0.21 & WC-Glucose & 0.0026 & 0.29 \\
\hline C-Index-TG & 0.0291 & 0.21 & C-Index-TG & 0.060 & 0.18 \\
\hline C-Index-Total cholesterol & 0.0088 & 0.25 & C-Index-Total cholesterol & $>0.05$ & - \\
\hline C-Index-LDL & 0.0037 & 0.28 & C-Index-LDL & $>0.05$ & - \\
\hline C-Index-Glucose & 0.0019 & 0.30 & C-Index-Glucose & 0.0001 & 0.37 \\
\hline
\end{tabular}

BMI - body mass index; TG - triacylglycerols; WHR - waist to hip ratio; HDL - high density lipoprotein; WHtR - waist to height ratio; WC - waist circumference; C-Index - coinicity index; LDL - low density lipoprotein;

TABLE 4. Correlations detected in the entire group of women and men before and after dietary intervention

\begin{tabular}{|c|c|c|c|c|c|}
\hline \multirow[b]{2}{*}{ Correlations } & \multicolumn{2}{|c|}{ Before } & \multirow[b]{2}{*}{ Correlations } & \multicolumn{2}{|c|}{ After } \\
\hline & $\mathrm{p}$ & $\begin{array}{c}\text { correlation } \\
\text { estimates value }\end{array}$ & & $p$ & $\begin{array}{c}\text { correlation } \\
\text { estimates value }\end{array}$ \\
\hline \multicolumn{6}{|c|}{ Group of women } \\
\hline WHR-TG & 0.0302 & 0.35 & WHR-TG & $>0.05$ & - \\
\hline WHR-LDL & 0.0036 & 0.45 & WHR-LDL & $>0.05$ & - \\
\hline WHR-Glucose & $>0.05$ & - & WHR-Glucose & 0.0024 & 0.47 \\
\hline WHtR-Glucose & 0.0182 & 0.38 & WHtR-Glucose & 0.0118 & 0.40 \\
\hline WC-LDL & 0.0061 & 0.43 & WC-LDL & $>0.05$ & - \\
\hline WC-Glucose & $>0.05$ & - & WC-Glucose & 0.0219 & 0.37 \\
\hline C-Index-LDL & 0.0074 & 0.42 & C-Index-LDL & $>0.05$ & - \\
\hline C-Index-Glucose & $>0.05$ & - & C-Index-Glucose & 0.0042 & 0.45 \\
\hline \multicolumn{6}{|c|}{ Group of men } \\
\hline BMI-TG & 0.0403 & 0.25 & BMI-TG & 0.0025 & 0.36 \\
\hline BMI-Glucose & $>0.05$ & - & BMI-Glucose & 0.0013 & 0.38 \\
\hline WHR-TG & $>0.05$ & - & WHR-TG & 0.0248 & 0.27 \\
\hline WHR-Glucose & 0.0229 & 0.27 & WHR-Glucose & 0.0240 & 0.27 \\
\hline WHtR-TG & $>0.05$ & - & WHtR-TG & 0.0069 & 0.32 \\
\hline WHtR-Glucose & $>0.05$ & - & WHtR-Glucose & 0.0011 & 0.38 \\
\hline WC-TG & $>0.05$ & - & WC-TG & 0.0085 & 0.31 \\
\hline WC-Glucose & $>0.05$ & - & WC-Glucose & 0.0006 & 0.41 \\
\hline C-Index-Glucose & $>0.05$ & - & C-Index-Glucose & 0.0058 & 0.33 \\
\hline
\end{tabular}

WHR - waist to hip ratio; TG - triacylglycerols; LDL - low density lipoprotein; WHtR - waist to height ratio; WC - waist circumference; C-Index - coinicity index; $\mathrm{BMI}$ - body mass index

The rapid, inexpensive and accurate diagnosis of possible metabolic risk factors for cardiovascular events, as well as NAFLD, using simple anthropometric measurements as screening tools in early diagnosis, seems to be a practical application of these tools in primary healthcare facilities [24].

In the scientific literature, the analysis of the usefulness of anthropometric indices such as BMI, WC, WHR, WHtR, and (although less frequently) C-Index have repeatedly been undertaken in the context of metabolic disorders and CHD risk assessment [30].

It is very important to take into consideration the fact that body structure and composition change with the ongoing processes of growth, maturation and aging of the body, which can have a direct impact on the modification of the normal range of anthropometric indicators [25]. This pattern does not apply to WHtR, because its value stems from the close relationship between changes in WC and height with age. This relationship is the biggest advantage of WHtR. In addition, this explains why the critical value of 0.5 is constant regardless of age. Another important characteristic of WHtR is the ease of taking measurements and estimating the result [25].

Body mass index although widely known and used in the assessment of nutritional status, is an ineffective tool in terms of assessing visceral obesity and metabolic disorders. Research 
conducted by Shields et al. [26] showed that despite the BMI values being within the normal or overweight range, at least two risk factors of CVD were identified in a group of men and women, and these correlated with an increase in the value of WC, WHR and WHtR. Patients with higher values of these indicators demonstrated also abnormalities in the form of increased plasma triacylglycerols (TG )and glucose, and a lower blood concentration of high density lipoprotein (HDL). These results clearly indicate the failure of the exclusive use of BMI in the early identification of patients at risk of CHD [26].

The main drawback of WC and WHR is that they do not relate to the height and changes in body weight. Epidemiological studies have shown that WC and WHR are independent predictors of many metabolic diseases, although their use is recommended in conjunction with BMI in order to increase the ability of these tools to predict cardiovascular risk [24].

The C-Index, although still poorly used, seems to be a very good determinant of body fat distribution, as it allows the comparison of 2 individuals differing in body weight and height. Increasingly, researchers have verified the validity of its use as a tool to assess the risk of metabolic disorders. A study conducted in both men and women by Haun et al. [25] indicated that the C-Index showed superior accuracy (compared to WHtR and WC) in the identification of visceral obesity in both sexes, however, WHtR was also accurate. Contrary to the recommendations of the WHO, WC is considered an unreliable parameter in the estimation of cardiovascular risk, although still better than BMI. The same authors pointed out that the only limitation in using the C-Index in population studies is the difficulty in calculating the denominator in the C-Index equation [25]. In order to determine the usefulness of anthropometric indicators in identifying CHD risk, a meta-analysis was performed which included a total population of 300000 diverse individuals in terms of ethnicity. Statistical analyses showed that, regardless of sex, WHtR was a significantly more reliable parameter associated with diabetes, hypertension, dyslipidemia and CHD, compared with WC and BMI [27].

In the available scientific literature, no studies have investigated the correlation between anthropometric tools and metabolic CHD risk factors in NAFLD patients, following an individualized nutrition plan.

According to the results presented in this study, after 6 months of dietary intervention all analyzed anthropometric indices significantly shifted toward lower values, in both sexes. Among the investigated biochemical parameters, only changes in TG levels attained statistical significance in the entire group $(p=0.0017)$, in women $(p=0.036)$ and in men $(p=0.019)$. Each of the anthropometric tools, with the exception of BMI, was significantly correlated with glucose level, both before and after the dietary intervention. In this group of patients with NAFLD, WC, WHR, WHtR, and the C-Index were reliable tools in predicting glucose tolerance. Importantly, although mean glucose concentration did not change significantly after the dietary intervention ( $p>0.05)$, we detected significant positive correlations between glucose and indices such as WHtR and the C-Index, which altered significantly after the dietary intervention ( $\mathrm{p}<0.0001)$. Correlations between WHtR and the C-Index and glucose (independently) were noticeably strong $(\mathrm{p} \leq 0.002)$ before and after the dietary intervention in the entire group. Decreasing visceral fat accumulation (due to lowered WC, WHR and WHtR values) resulted in decreased insulin resistance and increased lipolysis of abdominal adipose tissue. Waist to height ratio was the only parameter, before and after the dietary intervention, to be significantly correlated with serum TG concentration, which is directly associated with lipid metabolism: dietary fat intake and lipids released from adipose tissue lipolysis. The C-Index was strongly associated with lipids in the blood, but these correlations were only significant before the dietary intervention. In women, only the correlation between WHtR and glucose attained statistical significance before and after the diet. Other indices, such as WC, WHR and the C-Index, also correlated with glucose, but only after the dietary intervention $(\mathrm{p}<0.05)$. Simultaneously, WC, WHR and the C-Index correlated significantly with LDL-cholesterol, but only before the dietary intervention.

In men, the data analysis demonstrated that after the dietary intervention all of the analyzed anthropometric parameters (excluding C-Index) were positively correlated with both serum TG and glucose.

It should be emphasized that in the entire group of patients with NAFLD, each of the anthropometric parameters analyzed was reduced following the dietary intervention. This contributed to the reduced risk of CVD in this group by reducing major metabolic risk factors (TG, total cholesterol, low density lipoprotein and glucose, as well as an increase in HDL). It is worth noting that the improvement in these parameters was also associated with favorable changes within the fatty liver (as demonstrated in unpublished results).

Taking into consideration the results of this study, we can confirm the thesis presented by Haun et al. [25], that the C-Index and WHtR, despite being poorly used, are very useful in the assessment of body fat distribution (and visceral adipose tissue redistribution) and glucose metabolism. Waist to height ratio was strongly positively related to visceral fat accumulation and can be used as a sensitive tool for monitoring serum TG and glucose concentration, both before and after dietary intervention in men and women. Results of our study allow us to conclude that the reduction in body weight, and thus reduced WC, WHR, WHtR and the C-Index, contribute to the improvement in carbohydrate and lipid metabolism, hence stopping the progression of atherosclerosis. These results confirm that weight loss in patients with NAFLD is beneficial for improving glucose tolerance [7]. Waist to height ratio and the C-Index deserve particular attention due to their strong association with visceral fat distribution which indirectly results in impaired glucose and lipid metabolism and leads to intensified atherosclerosis [25]. This study demonstrated strong positive correlations between WHtR and the C-Index with serum $\mathrm{TG}$ and glucose concentrations. This confirmed the reports of other researchers on the usefulness of these indicators in the prediction of metabolic disorders which correlate with increased cardiovascular risk [25]. According to our data, the 
usefulness of these indicators in identifying those at metabolic risk of CHD among patients with NAFLD was demonstrated. Previous studies have shown that the main metabolic disorders caused by changes within the fatty liver (overproduction of glucose and TG), are independent risk factors for CHD, as well as other components of the metabolic syndrome (i.e. type 2 diabetes, dyslipidemia) [2]. Modifications in metabolism, occurring in NAFLD (lipolysis of adipose tissue, severe oxidative stress and insulin resistance) give rise to pathological changes within the cardiovascular system, thus combining fatty liver with the manifestation of CHD. Studies have shown that patients with NAFLD are at an increased risk of developing atherosclerosis and acute cardiovascular events, with an increase in overall mortality [31].

\section{CONCLUSIONS}

There is a strong correlation between the occurrence of NAFLD and CHD. This fact should encourage physicians (hepatologists) and other healthcare providers to modify procedures and schemes used in the diagnosis of NAFLD and other metabolic disorders. The widespread use of WHtR and the C-Index, due to their ease of use and cost-effectiveness, in screening and diagnosis in primary healthcare facilities, will allow confirmation of metabolic CHD risk in patients with NAFLD (or in others with risk factors) and provide them with appropriate medical care, either preventive or therapeutic. Other anthropometric tools, such as: BMI, WHR and WC also confirmed their usefulness in assessing the metabolic risk of CVD in NAFLD patients. All of these anthropometric tools analyzed in this study seem to be perfect for long-term observation of changes in body composition.

Acknowledgements: Supported by a grant from the NCN Nr N N404 150539. Conflict of interest: None.

\section{REFERENCES}

1. Yki-Jarvinen H. Nutritional modulation of nonalcoholic fatty liver disease and insulin resistance: human data. Curr Opin Clin Nutr Metab Care 2010;13:709-14.

2. Yki-Jarvinen H. Non-alcoholic fatty liver disease as a cause and a consequence of metabolic syndrome. Lancet Diabetes Endocrinol 2014;2(11):901-10.

3. Blachier M, Leleu H, Peck-Radosavljevic M, Valla DC, Roudot-Thoraval F. The burden of liver disease in Europe: A review of available epidemiological data. J Hepatol 2013;58:593-608.

4. Valantinas J, Apanaviciene DA, Maroziene L, Sveikata A. The prevalence of metabolic risk factors among outpatients with diagnosed nonalcoholic fatty liver disease in Lithuania. Med Sci Monit 2012;18:57-62.

5. Williamson RM, Price JF, Glancy S, Perry E, Nee LD, Hayes PC, et al. Prevalence of and risk factors for hepatic steatosis and nonalcoholic fatty liver disease in people with type 2 diabetes: the Edinburgh type 2 diabetes study. Diabetes Care 2011;34:1114-39.

6. Zelber-Sagi S, Ratziu V, Oren R. Nutrition and physical activity in NAFLD: an overview of the epidemiological evidence. World J Gastroenterol 2011;17:3377-89.

7. Conlon BA, Beasley JM, Aebersold K, Jhangiani SS, Wylie-Rosett J. Nutritional management of insulin resistance in nonalcoholic fatty liver disease (NAFLD). Nutrients 2013;5:4093-114.
8. Walenbergh SM, Koek GH, Bieghs V, Shiri-Sverdlov R. Non-alcoholic steatohepatitis: the role of oxidized low-density lipoproteins. J Hepatol 2013;58:801-10.

9. Fan JG, Cao HX. Role of diet and nutritional management in non-alcoholic fatty liver disease. J Gastroenterol Hepatol 2013;28 Suppl 4:81-7.

10. Ueno T, Sugawara H, Sujuku K, Hashimoto O, Tsuji R, Tamaki S, et al. Therapeutic effects of restricted diet and exercises in obese patients with fatty liver. J Hepatol 1997;27:103-7.

11. Vajro P, Lenta S, Socha P, Dhawan A, McKiernan P, Baumann U, et al. Diagnosis of nonalcoholic fatty liver disease in children and adolescents: Position paper of the espghan hepatology committee. J Pediatr Gastroenterol Nutr 2012;54:700-13.

12. Ogden CL, Carroll MD, Kit BK, Flegal KM. Prevalence of obesity and trends in body mass index among U.S. children and adolescents. 1999-2010. JAMA 2012;307:483-90.

13. Uemura K, Pisa Z. Trends in cardiovascular disease mortality in industrialized countries since 1950. World Health Stat Q 1988;3-4:155-78.

14. Ding D, Li X, Qiu J, Li R, Zhang Y, Su D, et al. Serum lipids, apolipoproteins and mortality among coronary artery disease patients. Biomed Res Int 2014;2014:709756. doi: 10.1155/2014/709756.

15. Kannel WB, McGee D, Gordon T. A general cardiovascular risk profile: the Framingham Study. Am J Cardiol 1976;38:46-51.

16. Menotti A, Keys A, Blackburn H, Kromhout D, Karvonen M, Nissinen A, et al. Comparison of multivariate predictive power of major risk factors for coronary heart diseases in different countries: results from eight nations of the Seven Countries Study, 25-year follow-up. J Cardiovasc Risk 1996;1:69-75.

17. Rose G, Hamilton PS, Keen H, Reid DD, McCartney P, Jarrett RJ. Myocardial ischaemia risk factors and death from coronary heart disease. Lancet 1977;1:105-9.

18. Ko DT, Wijeysundera HC, Udell JA, Vaccarino V, Austin PC, Guo H, et al. Traditional cardiovascular risk factors and the presence of obstructive coronary artery disease in men and women. Can J Cardiol 2014;30:820-6.

19. Logstrup S, editor. European Cardiovascular Disease Statistics 2008 edition. Brussels: European Heart Network; 2008.

20. Sans S, Kesteloot H, Kromhout D. The burden of cardiovascular diseases mortality in Europe. Task Force of the European Society of Cardiology on Cardiovascular Mortality and Morbidity Statistics in Europe. Eur Heart J 1997;12:1231-48.

21. Obesity: Preventing and Managing the Global Epidemic. Report of a WHO Consultation on Obesity. Geneva: World Health Organization; 2000. p 5-13.

22. Kannel WB, Wilson PW, Nam BH, D'Agostino RB. Risk stratification of obesity as a coronary risk factor. Am J Cardiol 2002;90:697-701.

23. Tonstad S. Hjermann I. A high risk score for coronary heart disease is associated with the metabolic syndrome in 40-year-old men and women. J Cardiovasc Risk 2003;10:129-35.

24. Almeida RT, Almeida MM, Araujo TM. Abdominal obesity and cardiovascular risk: Performance of anthropometric indexes in women. Arq Bras Cardiol 2009;92:345-50.

25. Haun DR, Pitanga FJ, Lessa I. Waist/height ratio compared with other anthropometric indicators of obesity as a predictor of high coronary risk. Rev Assoc Med Bras 2010;56:705-11.

26. Shields M, Tremblay MS, Connor Gorber S, Janssen I. Abdominal obesity and cardiovascular disease risk factors within body mass index categories. Health Rep 2012;23:7-15.

27. Ashwell M, Hsieh SD. Six reasons why the waist-to-height ratio is a rapid and effective global indicator for health risks of obesity and how its use could simplify the international public health message on obesity. Int J Food Sci Nutr 2005;56:303-7.

28. Lemos-Santos MGF, Valente JG, Gonçalves-Silva RM, Sichieri R. Waist circumference and waist-to-hip ratio as predictors of serum concentration of lipids in Brazilian men. Nutrition 2004;20:857-62.

29. Kunachowicz H, Nadolna I, Iwanow K. Wartość odżywcza produktów spożywczych i typowych potraw. Warszawa: PZWL; 2001.

30. Okosun IS, Choi ST, Boltri JM, Parish DC, Chandra KM, Dever GE, et al. Trends of abdominal adiposity in White, Black, and Mexican-American adults. 1988 to 2000. Obes Res 2003;11:1010-7.

31. Perazzo H, Poynard T, Dufour JF. The interactions of nonalcoholic fatty liver disease and cardiovascular diseases. Clin Liver Dis 2014;18:233-48. 